Acta vet. scand. $1981,22,535-552$.

From the Department of Pathology, Faculty of Veterinary Medicine, Swedish University of Agricultural Sciences. Uppsala and the Swedish

Research Institute of National Defence, Department 4, Stockholm.

\title{
INTERFERENCE OF MYCOTOXINS WITH PRENATAL DEVELOPMENT OF THE MOUSE
}

\section{OCHRATOXIN A INDUCED TERATOGENIC EFFECTS IN RELA'TION TO THE DOSE AND STAGE OF GESTATION}

\author{
By
}

R. G. Arora and H. Frölén

\begin{abstract}
ARORA, R. G. \& H. FRöLÉN: Interference of mycotoxins with prenatal development of the monse. II. Ochratoxin A induced teratogenic effects in relation to the dose and stage of gestation. Acta vet. scand. 1981, 22, 535-552. - Ochratoxin A was dissolved in corn oil and administered by stomach tube to pregnant CBA mice in varying dosages. On gestation day 8 or 9 the dams were treated with a dose of either 1,2 or $4 \mathrm{mg} / \mathrm{kg}$ body weight and on 1 of various other days $(2,4,6-7,10-14,16)$ or 2 days prior to conception they were supplied with a dose of $4 \mathrm{mg} / \mathrm{kg}$. The highest amount of the toxin given on day 7,8 or 9 decreased the prenatal survival and on day 9 diminished the foetal growth. A marked impairment in foetal growth also resulted from treatment before conception. Overt craniofacial anomalies were produced only by exposure on day 8 or 9 and their incidence, multiplicity and severity increased with increasing dosage, the peak effect being on day 9 .

A study of the anatomical features of the craniofacial skeleton disclosed the failure of closure of neurocranium and an abnormal configuration, position and size of the bones of the base and lateral walls of the skull.
\end{abstract}

mycotoxin; ochratoxin A; dose effect; teratogenicity; mouse.

In our initial report (Arora et al. 1981) the effects of prenatal exposure to mycotoxins - aflatoxin $B_{1}$, ochratoxin $A$ and zearalenone on the foetal development of mice have been described. Among the mycotoxins tested, ochratoxin A was found to be the most potent teratogen. A multitude of neural tube closure defects with associated abnormalities of the skeleton of the skull, spine and the thoracic cage occurred in the foetuses exposed to toxin 
during intrauterine development on post conception (p.c.) day 8 or 9. These observations formed the basis for undertaking a further series of experiments with an ultimate aim in mind to fill in some of the many gaps that remain in the present day knowledge of abnormal foetal development resulting from maternally ingested ochratoxin. Studies pertaining to the detailed description of the pathomorphological characteristics of the various malformations seen in full term foetuses and the nature of cellular events associated with the various stages of abnormal foetogenesis after exposure will form the subject of future publications.

The present paper concerns the teratogenic response of the embryos to various doses of ochratoxin $A$ administered during the critical stages of development (day 8-9). In addition the effects, if any, were also examined following administration before or after conception, during various other stages of embryogenesis.

\section{MATERIAL AND METHODS}

The details of the experimental procedures, the animals used and the methods of analysis of the material were the same as described previously (Arora et al.).

In the first series of experiments the pregnant mice were given perorally a single dose of either 1,2 or $4 \mathrm{mg} / \mathrm{kg}$ ochratoxin A (dissolved in corn oil) on the morning of either p.c. day 8 or 9 (vaginal plug day $=$ p.c. day 1 ).

The females in the second experiment were given a dose of $4 \mathrm{mg} / \mathrm{kg}$ ochratoxin on one of the other gestation days including 2 days prior to mating. The controls in each series received an equivalent amount of corn oil (Exp. I) or were kept untreated (Exp. II). The design of the 2 experiments is illustrated in Table 1. The statistical methods applied to measure the effect of toxin for each treatment day and the reason for their use are stated in the Appendix given at the end of this paper.

All the experimental and control animals in 2 of the series were sacrificed on p.c. day 19 with a few exceptions when they were sacrificed on p.c. day 18 due to unavoidable reasons.

The uterine horns were opened and examined for both viable and dead foetuses including the number of resorption sites. After weighing the viable foetuses they were subjected to morphological examination according to the schedule mentioned in the 


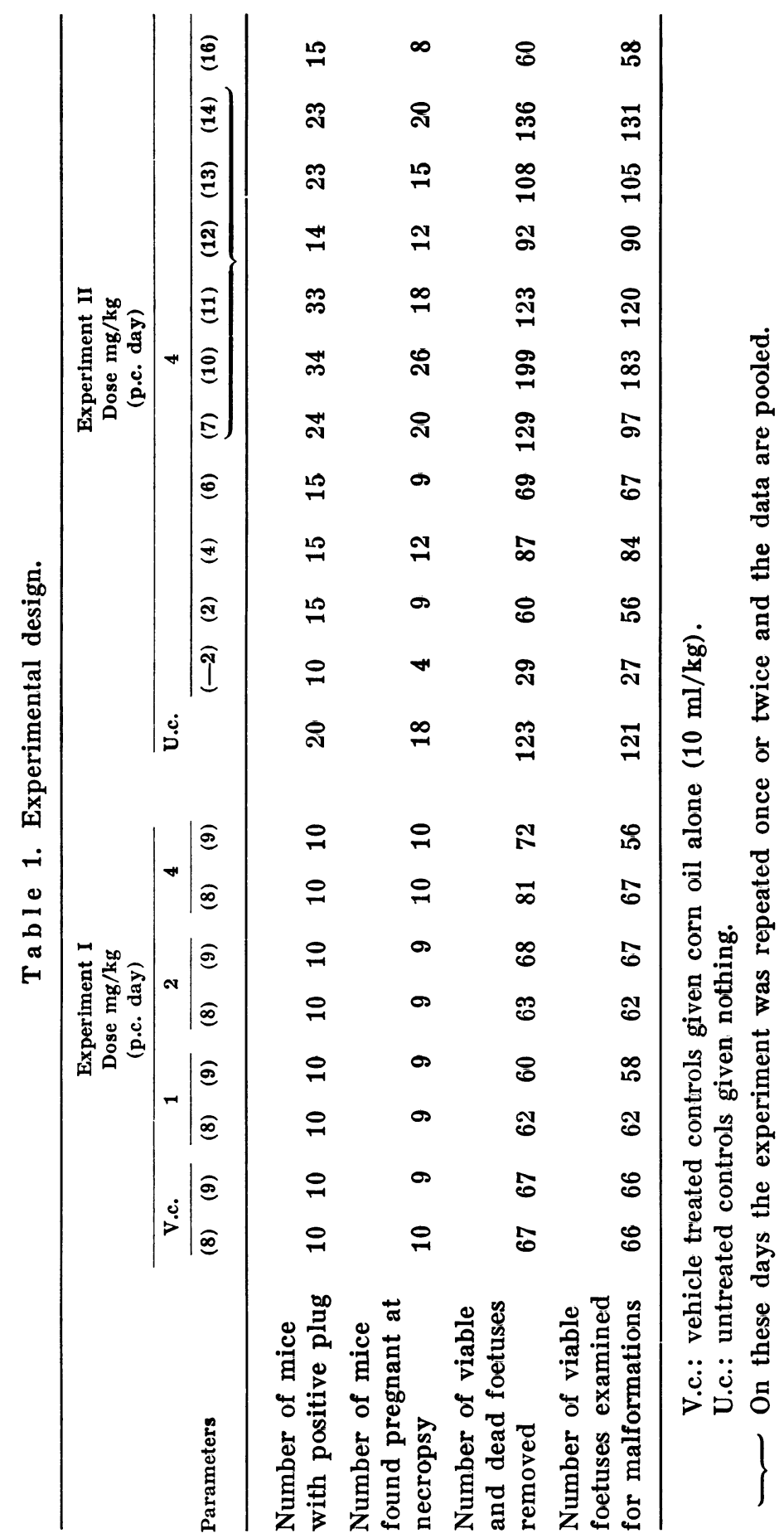


previous paper. To facilitate the analysis and proper identification of bone and cartilage in the same specimen, the foetuses prior to staining with alizarine red-S were stained in alcian blue soluton according to the method of Peters (1977) and examined under stereo-microscope for morphological evaluation of skeletal anomalies.

\section{Experiment $I$}

\section{RESULTS}

In Table 2 are shown the pooled data on the prenatal development of mice exposed to various doses of ochratoxin or corn oil alone. Increased foetal mortality and growth inhibition were noticed in litters treated with highest dose $(4 \mathrm{mg} / \mathrm{kg})$. The lower doses apparently did not alter the incidence of dead embryos; the mean pup weight in certain litters, however, appeared to be somewhat lower as compared to controls.

Frequency of gross abnormalities. The number of malformed foetuses among the treated dams distinctly raised with increasing dose levels and was clearly influenced by the treatment day (Table 2, Fig. 1). Following treatment in doses of $1-4 \mathrm{mg} / \mathrm{kg}$ on p.c. day 8 the percentage incidence of malformed foetuses ranged from $0-16$ as compared to 29-91 with

T a b l e 2. Prenatal effects of various doses of ochratoxin $A$ on the mouse foetal development.

\begin{tabular}{|c|c|c|c|c|c|c|c|c|}
\hline \multirow[t]{2}{*}{$\begin{array}{l}\text { Dose } \\
\mathrm{mg} / \mathrm{kg}^{*}\end{array}$} & \multirow{2}{*}{$\begin{array}{l}\text { Gesta- } \\
\text { tion } \\
\text { day }\end{array}$} & \multirow{2}{*}{$\begin{array}{l}\text { Number } \\
\text { of im- } \\
\text { plants ** }\end{array}$} & \multirow{2}{*}{$\begin{array}{l}\text { Number } \\
\text { of } \\
\text { resorp- } \\
\text { tions }\end{array}$} & \multicolumn{2}{|c|}{ Late deaths } & \multirow{2}{*}{$\begin{array}{l}\text { Foetal weight } \\
\begin{aligned} \text { (g) } \\
\bar{x} \stackrel{\text { s.e.m. }}{ \pm}\end{aligned}\end{array}$} & \multicolumn{2}{|c|}{$\begin{array}{l}\text { Survivors } \\
\text { malformeda }\end{array}$} \\
\hline & & & & Number & $r \%$ & & Number & $\%$ \\
\hline \multirow{2}{*}{ (V.c.) 0} & 8 & $71(10)$ & 4 & - & - & $1.04 \pm 0.02$ & - & - \\
\hline & 9 & $72(9)$ & 6 & - & - & $1.09 \pm 0.02$ & - & 一 \\
\hline \multirow{2}{*}{1} & 8 & $68(9)$ & 6 & - & - & $1.09 \pm 0.01$ & - & - \\
\hline & 9 & $62(9)$ & 2 & 1 & 1.7 & $0.99 \pm 0.02$ & 17 & 29.3 \\
\hline \multirow{2}{*}{2} & 8 & $69(9)$ & 6 & 1 & 1.6 & $0.91 \pm 0.02$ & 5 & 8.1 \\
\hline & 9 & $68(9)$ & - & 1 & 1.5 & $0.91 \pm 0.02$ & 28 & 41.8 \\
\hline \multirow{2}{*}{4} & 8 & $91(10)$ & 10 & $141^{\prime}$ & 17.3 & $0.93 \pm 0.02$ & 11 & 16.4 \\
\hline & 9 & $76(10)$ & 4 & 162 & 22.2 & $0.62 \pm 0.02$ & 51 & 91.1 \\
\hline
\end{tabular}

* doses were prepared in corn oil and administered p.o. in a volume of $10 \mathrm{ml} / \mathrm{kg}$ body weight.

* * number of females treated at each dose level is given in parenthesis.

a total number of surviving foetuses included for calculating the percentage of survivors malformed is given in Table 1. 


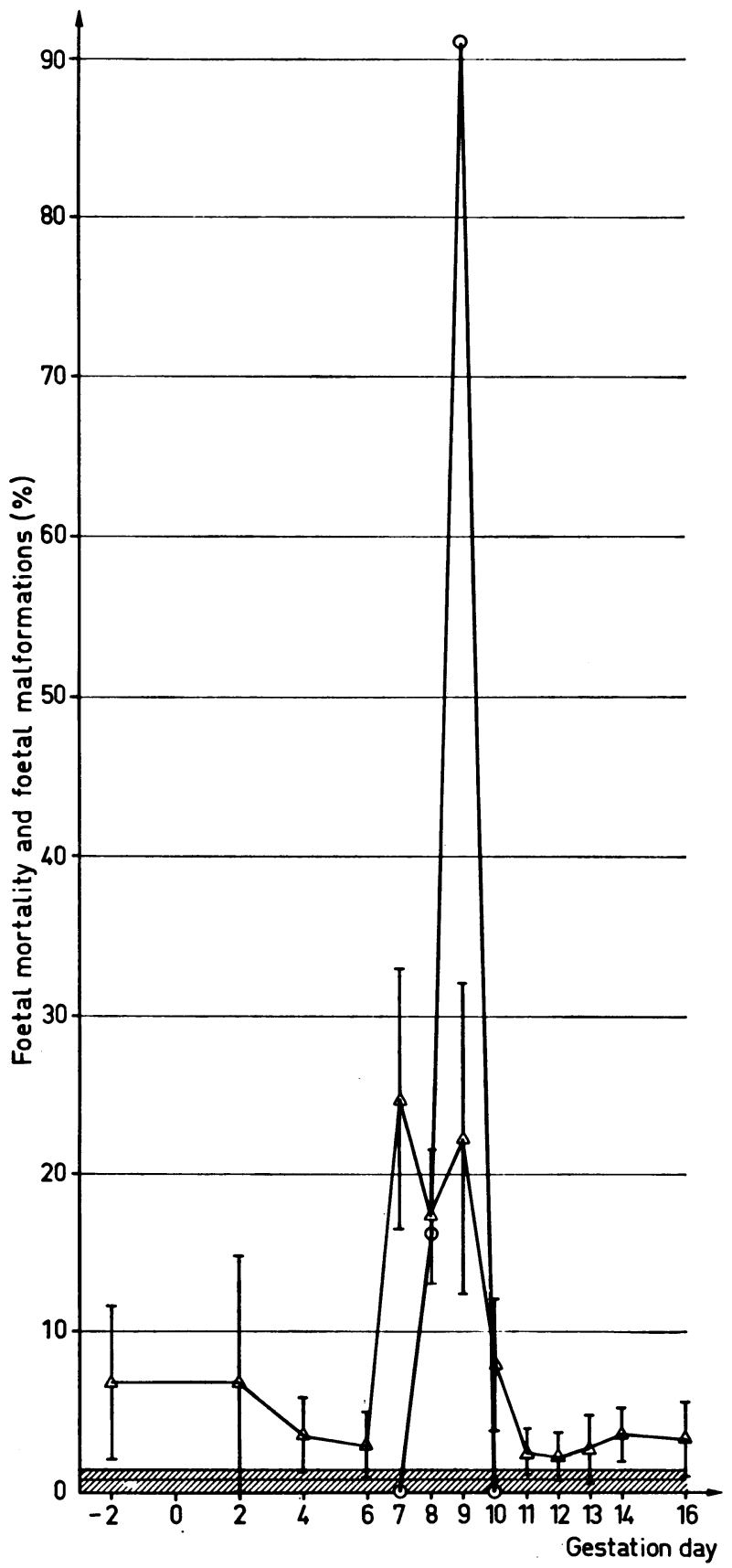

Figure 1. Frequencies of foetal deaths and anomalies due to ochratoxin $\mathrm{A}(4 \mathrm{mg} / \mathrm{kg})$ given at one of the various stages of gestation or two days (-2) prior to conception. $\triangle \longrightarrow \triangle$ : Foetal mortality, $\mathrm{O} \mathrm{O}:$ Foetal anomalies, 


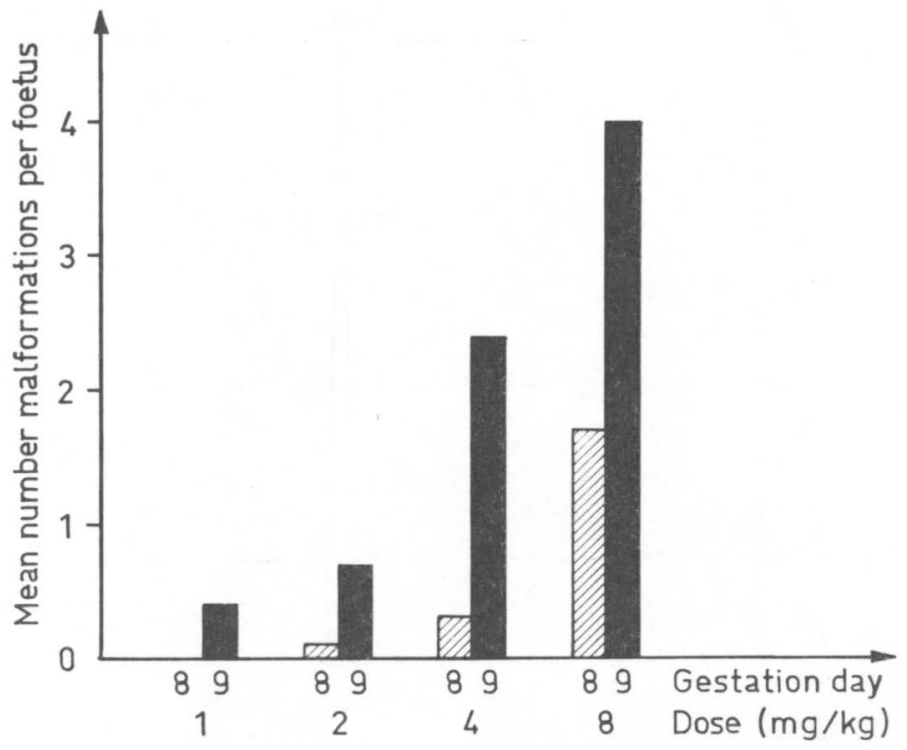

Figure 2. Mean number of anomalies per foetus after maternal exposure to various doses of ochratoxin $A$. The values obtained by using a dose of $8 \mathrm{mg} / \mathrm{kg}$ are taken from preceding paper (Arora et al.) for comparison.

corresponding doses administered on day 9. Likewise the multiplicity and severity reflected in the mean number of malformations per foetus was much greater in the group exposed on day 9 than in that exposed on day 8 with any dose level (Fig. 2).

Types of a nomalies. The induction of various types of anomalies is recorded in Table 3. As expected from the results described earlier (Arora et al.), the great majority of abnormalities was restricted to the craniofacial region. Varying degree of brain exposure (exencephaly) was the most common and consistently produced malformation. Frequently the eyes in such foetuses were not formed or underdeveloped (microphthalmia). Mid facial clefts of varying degree of severity, hypoplastic jaws and the apparent lack of development of external nares occurred exclusively in foetuses exposed to the highest dose on p.c. day 9.

Skeletal abnormalities other than those of the head and face were much less common and characterized by the fusion between 2 adjacent ribs and or vertebrae. These abnormalities were usually not induced by doses below $4 \mathrm{mg} / \mathrm{kg}$. As the most striking and regularly occurring defects were observed in the cranio- 
Mycotoxins and prenatal development. II.

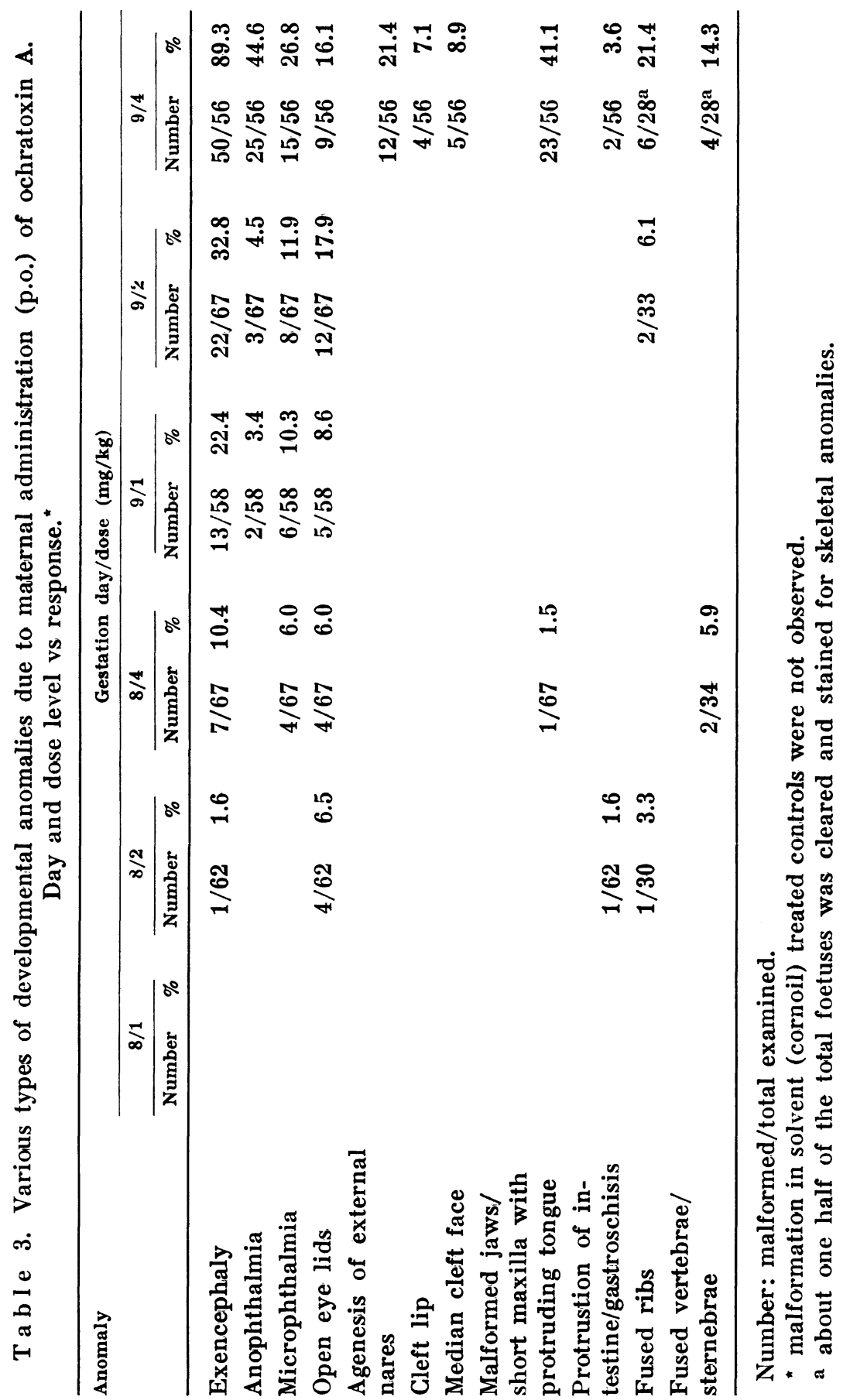


facial skeleton, these will now be considered in somewhat greater detail. For orientation and comparison the normal appearance of the skull is shown in Figs. 3-4. In exencephalic foetuses the cranial bones which normally cover the brain dorsally were practically all missing. However, the rudimentary bony fragments of the parts that form the lateral walls of the skull were readily identifiable in most cases. The base of the skull in general, was narrow and also reduced in its anterioposterior diameter. Basal bones were all present but abnormal (Figs. 5 a and 5 b).

The basisphenoid most often was severily hypoplastic, abnormally configurated and deviated forward and upward. In extreme cases its body was deeply cleft anteriorly or bipartite altogether (Fig. $5 \mathrm{~b}$ ). The wings appeared folded and contracted. The presphenoid situated rostrally to the basisphenoid was unossified and remained as an atrophic chondrified structure. Caudally to basisphenoid, the basioccipitale appeared somewhat narrow and slightly raised above the normal level at its rostral end.

Exoccipitalia were thickened but reduced in size and the supraoccipitale represented by a mere thin rim of membrane with no evidence of ossification. The auditory capsules sometimes appeared bigger than normal and displaced ventrally. In cases where the external nares were not formed the nasal cavity was narrow and the septum greatly thickened and deviated laterally from the mid line. The ethmoid slanting rostrodorsally was completely cartilaginous in both normal and malformed specimens. In severely malformed heads the ethmoid or nasoturbinates were difficult to locate while in less severe cases unidentifiable cartilagenous remnants were seen.

Among the bones of the face (viscerocranium) the most severely affected were the maxillae and premaxillae. In cases of complete mid facial clefts only rudimentary fragments of these bones displaced on either side of the head were observed. The mandible appeared larger and heavier than normal but remained intact.

The orbits were similarly malformed and appeared shallower than normal on account of the small size, irregular shape and malpositioning of the bones that take part in their formation. The alisphenoid which normally forms the majority of the medial wall of the orbit was severely retarded and contracted. The squamosal, zygomatic and temporal bones were similarly reduced and inclined internally. 
F i g u r e s $3-5$. Photographs of skulls of foetuses from control and experimental mice killed on day 19 of pregnancy. Alcian blue - alizarin red staining. All are at the same magnification $(x 7)$.

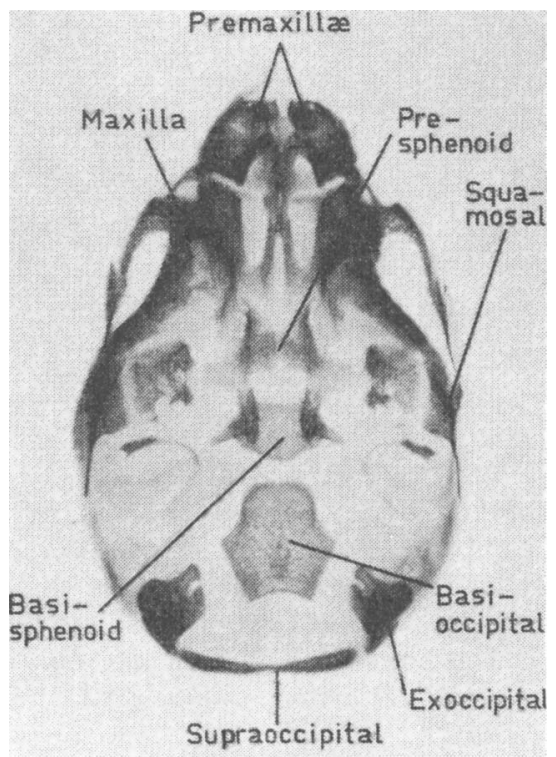

F ig u r e 3. Dorsal view of a normal foetal skull. The cranial vault has been removed to visualize the basal bones.

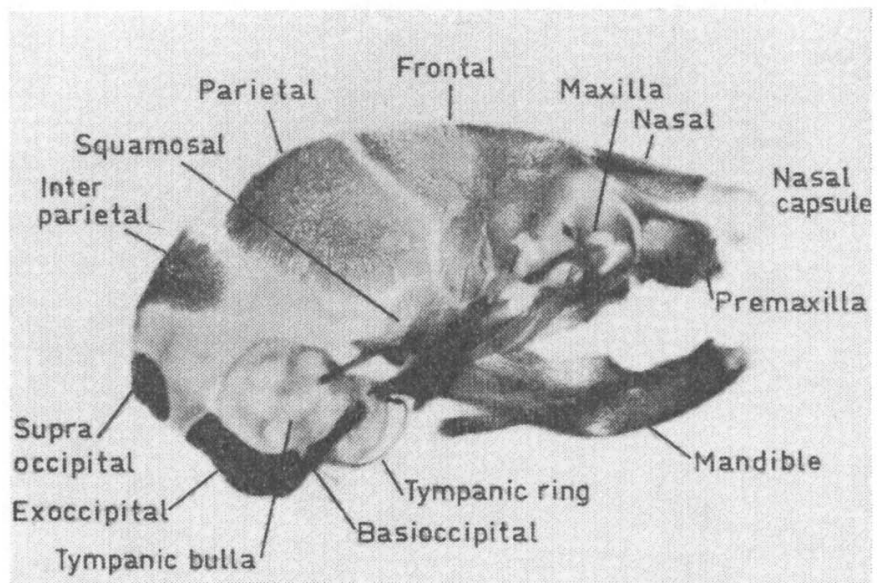

Figure 4. Right lateral view of a normal foetal skull showing various bones of the cranial vault and face. 


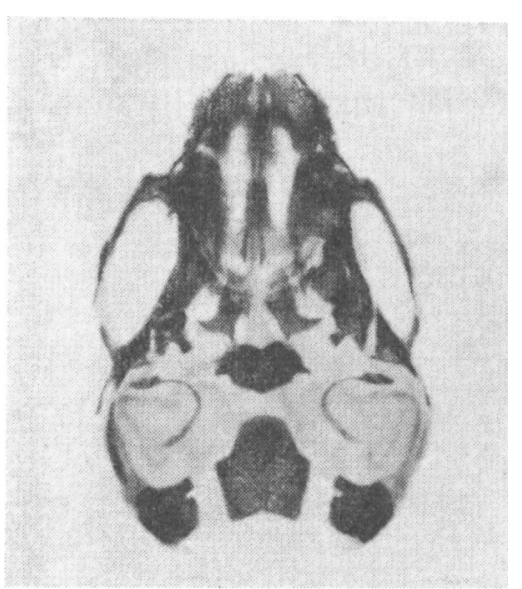

Figure 5 a. Dorsal view of the skull of an exencephilic foetus exposed on developmental day 9 to ochratoxin A $(4 \mathrm{mg} / \mathrm{kg})$. Bones of the cranial vault are practically all missing and the overall size of the skull reduced. Basal bones are all present but formed abnormally. (See text).

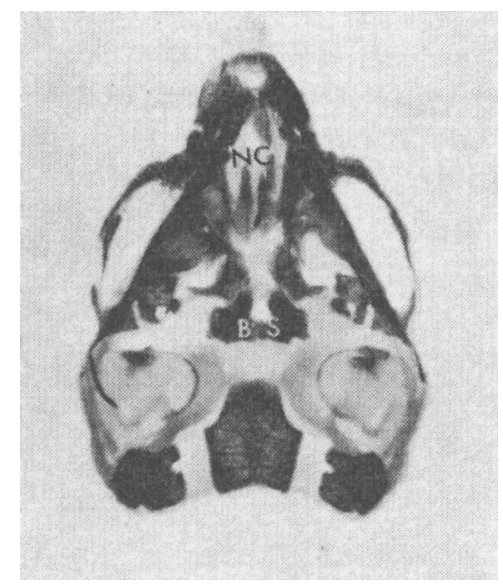

Fig u re $5 \mathrm{~b}$. Dorsal view of the skull of an exencephalic foetus exposed on day 9 of development to ochratoxin A $(4 \mathrm{mg} / \mathrm{kg})$. This skull shows more severe alterations than shown in Fig. 5 a. Note abnormal configuration of nasal cavity (N.C.) and a bipartite basisphenoid (B.S.)

T a b l e 4. Effects of ochratoxin A (4 mg/ $\mathrm{kg})$ administered p.o. to mice before or after conception, during gestation.

\begin{tabular}{|c|c|c|c|c|c|c|}
\hline \multirow{2}{*}{$\begin{array}{l}\text { Gesta- } \\
\text { tion } \\
\text { day }\end{array}$} & \multirow{2}{*}{$\begin{array}{c}\text { Number } \\
\text { of im- } \\
\text { plants }\end{array}$} & \multirow{2}{*}{$\begin{array}{l}\text { Number } \\
\text { of } \\
\text { resorp- } \\
\text { tions }\end{array}$} & \multicolumn{2}{|c|}{$\begin{array}{l}\text { Late foetal } \\
\text { deaths }\end{array}$} & $\begin{array}{l}\text { Foetal weight } \\
\text { (g) }\end{array}$ & \multirow[t]{2}{*}{$\begin{array}{c}\text { Survivors } \\
\text { malformed }\end{array}$} \\
\hline & & & Number & $\%$ & & \\
\hline-2 & 34 & 5 & 2 & 6.9 & $0.58 \pm 0.03$ & - \\
\hline 2 & 67 & 7 & 4 & 6.7 & $0.87 \pm 0.02$ & - \\
\hline 4 & 95 & 8 & 3 & 3.5 & $0.94 \pm 0.01$ & - \\
\hline 6 & 75 & 6 & 2 & 2.9 & $0.90 \pm 0.01$ & - \\
\hline 7 & 148 & 19 & 32 & 24.8 & $0.61 \pm 0.01$ & - \\
\hline 10 & 214 & 15 & 16 & 8.0 & $0.67 \pm 0.02$ & - \\
\hline 11 & 135 & 12 & 3 & 2.4 & $0.66 \pm 0.03$ & - \\
\hline 12 & 93 & 1 & 2 & 2.2 & $0.90 \pm 0.01$ & - \\
\hline 13 & 121 & 13 & 3 & 2.8 & $0.63 \pm 0.01$ & - \\
\hline 14 & 143 & 7 & 5 & 3.7 & $0.64 \pm 0.01$ & - \\
\hline 16 & 61 & 1 & 2 & 1.6 & $1.05 \pm 0.02$ & - \\
\hline $\begin{array}{l}\text { Untreated } \\
\text { controls }\end{array}$ & 129 & 6 & 2 & 1.6 & $1.05 \pm 0.02$ & - \\
\hline
\end{tabular}

Females treated on p.c. days $7,10,11,13,14$ were killed on p.c. day 18 , others were killed on day 19.

-2: females treated 2 days before mating. 


\section{Experiment II}

The results are summarized in Table 4 and Fig. 1. No anatomical anomalies were induced after exposure at any gestational stage. The prenatal death rate particularly after treatment on day 7 was considerably higher than the control level. The relative low average foetal weight in litters treated on this as well as on days 10,11, 13 and 14 (Table 4) does not seem to be the effect of toxin on account of the fact that the foetuses were removed on p.c. day 18, a day earlier than their control counterparts or those exposed at other stages of embryogenesis. Severe growth retardation, comparable to the extent caused by a similar dose given on p.c. day 9 (Experiment $I$ ) was, however, seen in foetuses whose mothers were treated prior to mating.

The statistical significance of the results shown in Fig. 1 (Experiment I and II) is discussed and commented upon in the Appendix. Table $A$ and $B$ in this appendix show the distribution of responding foetuses from each individual litter (treatment dose $4 \mathrm{mg} / \mathrm{kg}$ ).

\section{DISCUSSION}

The present investigation has amply shown that ochratoxin $A$ is a potentially teratogenic and foetocidal as well as growth retardant. These observations confirm and add to the prenatal effects of this mycotoxin previously reported in the embryos of mouse (Hayes et al. 1974, Hood et al. 1978), rat (Brown et al. 1976, Moré \& Galtier 1974, Still et al. 1971), and hamster (Hood et al. 1976). All these reported observations as well as those made here reveal that the mouse embryos are among the most susceptible to the ochratoxin teratogenesis. However, under the present experimental conditions there were distinct differences in the teratogenic response from others who also used the mouse as the test animal, but a different route (i.p.) of administration. Our results achieved after oral treatment suggest that the stages of embryogenesis prior to day 7 or after day 9 are not very susceptible to the action of ochratoxin. A reduced foetal survival was caused by treatment on day 7, 8 and 9 and following exposure on day 9 also a marked impairment in foetal growth. Foetuses from mothers treated prior to pregnancy appeared stunted and lighter in weight. The induction of anomalies, however, resulted only when females were dosed on either day 8 or 9 of pregnancy. 
These findings are in contrast to the observations of Hayes et al. (1974) who reported foetocidal and teratogenic effects of the compound injected on either of the gestational days (7-12) tested. Their data indicating the greatest effect of the toxin when given on day 8 are also in disagreement to ours. In the current study, a dose related increased incidence of foetal anomalies, though, occurred after treatment on either day (8-9) of gestation, the effect induced by any dosages being far greater in litters exposed on day 9.

One possible explanation for differences between the present results and those of Hayes et al. may be the mode of administration of the teratogen (oral versus i.p.), although, as pointed out in our previous report (Arora et al.) the possibility of other variables like strain of mice, solvent used, maternal or external environments can not be ruled out. Nevertheless, considering administration by stomach tube as the most acceptable route for testing teratogenicity of food chemicals/contaminants, the present results appear to be more reliable than those reported by employing an unnatural route, viz i.p.

The period of embryonic development during which mycotoxin triggered cellular alterations leading to anomalous morphology of the craniofacial complex coincides with the process of formation and folding up of the cephalic neural tube. This is in complete agreement to the concept that most devastating abnormalities of the head and face are produced in embryos subjected at this stage (anterior neuropore open) to various types of trauma (Rugh 1968). Our results are also in accordance to the view that once the neuropore closes, the midline closure defects (exencephaly among others) no longer occur (Skalko et al. 1971). In our working experience with various stages of normal embryogenesis in the strain of mice used here, the brain tube is closed completely after the end of day 9 of development. Thus it is presumable that the closed neural tube is either not accessible to the mycotoxin or the amount crossing the maternal barrier at this or later stages, to reach the embryo, is insufficient. The latter possibility seems to be more likely in view of our preliminary investigation with radiolabelled ochratoxin ( $A p$ pelgren \& Arora 1980). After its administration on day 10 or 17 most of the radioactivity remained confined to the uterine wall or in the placenta. However, it remains to be investigated if such offsprings when born would not be functionally deficient. Such 
a possibility seems to be rare particularly in view of the recent study by Szczech \& Hood (1981) indicating the induction of necrosis in foetal brain by multiple exposure to ochratoxin during late gestation (days 15-17), although no such effect was produced by a single dose treatment on either of these days.

As regards the malformations themselves, they were confined to the head and face region and were, in general, of the same type as noted in the preceding paper. Severe deformities of thoracic cage and spine were not produced, however, since the dosages used here were $1 / 8$ to $1 / 2$ of that used before. Furthermore there were no indications of maldevelopment of ear or tail either.

The abnormal development of craniofacial complex may be interrelated to the brain and skull, i.e. it may be the consequence of either primary defects of the skeletal element with secondary effects on the brain or the brain malformations may be primary with secondary deformation of the cranial skeleton.

A detailed examination of cleared and stained preparations revealed morphological alterations in nearly all skeletal structures of the skull and thus appeared to be the prominent defects associated with the visible malformations of the brain and face. The survey of the literature shows that these skeletal anomalies have not been of much concern to the experimental teratologists as they are considered to be secondary to brain closure. MarinPadilla (1965) who made a detailed analysis of the cranial bones from spontaneous cases of human cranio-schisis reported that the base of the skull was fundamentally abnormal in these cases and thus constituted to be the cause rather than a consequence of the schisis. Further, it was suggested by both clinical (MarinPadilla 1965) and experimental observations (Marin-Padilla \& Ferm 1965, Marin-Padilla 1966) that the deformation of the cranial base is possibly related to a primary disturbance in the cephalic mesoderm occurring before the closure of anterior neuropore. Whether a similar pathomorphogenesis holds true for the ochratoxin induced malformations is dfificult to ascertain from the present experiments. Nevertheless, the over all skeletal defects of basal and dorsal neurocranium appear to be similar to those described in human malformations and point out the need for a sequential analysis of embryological evolution of these malformations to be reported in later communications. 


\section{ACKNOWLEDGEMENT}

The authors thank Professors A. Nilsson and G. Winqvist for reviewing the manuscript and Ola Hertzberg, fil. dr., for excellent help and comments on statistical analysis. The financial support for the work was provided by SAREC, the Swedish Agency for Research Cooperation with developing countries.

\section{REFERENCES}

Appelgren, L. E. \& R. G. Arora: Distribution studies of ${ }^{14} \mathrm{C}$-labelled aflatoxin $B_{1}$ and ochratoxin $A$ in pregnant mice. Presented in Int. nat. Conf. Vet. Pharmacol. Toxicol. Therapeut. Churchill College Cambridge, July 28 - Aug. 1, 1980.

Arora, R. G., H. Frölén \& A. Nilsson: Interference of mycotoxins with prenatal development of the mouse. I. Influence of aflatoxin $B_{1}$, ochratoxin A and zearalenone. Acta vet. scand. 1981, 22, 524534.

Brown, M. H., G. M. Szczech \& B. P. Purmalis: Teratogenic and toxic effects of ochratoxin A in rats. Toxicol. appl. Pharmacol. 1976, 37, 331-338.

Hayes, A. W., R. D. Hood \& H. L. Lee: Teratogenic effects of ochratoxin $\mathrm{A}$ in mice. Teratology 1974, 9, 93-98.

Hood, R. D., M. H. Kuczuk \& G. M. Szczech: Effects in mice of simultaneous prenatal exposure to ochratoxin A and T-2 toxin. Teratology 1978, 17, 25-30.

Hod, R. D., M. J. Naughton \& A. W. Hayes: Prenatal effects of ochratoxin $\mathrm{A}$ in hamsters. Teratology $1976,13,11-14$.

Marin-Padilla, M.: Study of the skull in human cranioschisis. Acta anat. (Basel) 1965, 62, 1-20.

Marin-Padilla, M.: Mesodermal alterations induced by hypervitaminosis A. J. Embryol. exp. Morphol. 1966, 15, 261—269.

Marin-Padilla, M. \& V. H. Ferm: Somite necrosis and developmental malformations induced by vitamin $\mathrm{A}$ in the golden hamster. J. Embryol. exp. Morphol. 1965, 13, 1-8.

Moré, J. \& P. Galtier: Toxicité de l'ochratoxine A. I. Effect embryotoxique et tératogène chez le rat. (Toxicity of ochratoxin A. I. Embryotoxic and teratogenic effect in rat). Ann. Réch. vét. $1974,5,167-178$.

Peters, P. W. J.: Double staining of foetal skeletons for cartilage and bone. In: Methods in Prenatal Toxicology: Evaluation of Embryotoxic Effects in Experimental Animals. Neubert, D., H. J. Merker \& T. E. Kwasigroch (eds.). Georg Thiem Publishers, Stuttgart 1977, p. 153-154.

Rugh, R.: The Mouse. Its Reproduction and Development. Burges, Minneapolis 1968, p. 116.

Skalko, R. G., D. S. Packard Jr, R. N. Schwendimann \& J. R. Raggio: The teratogenic response of mouse embryos to 5-bromodeoxyuridine. Teratology 1971, 4, 87-94. 
Still, P. E., A. W. Macklin, W. E. Ribelin \& E. B. Smalley: Relationship of ochratoxin A to foetal death in laboratory and domestic animals. Nature (Lond.) 1971, 234, 563-564.

Szczech, G. M. \& R. D. Hood: Brain necrosis in mouse foetuses transplacentally exposed to the mycotoxin ochratoxin A. Toxicol. appl. Pharmacol. 1981, 57, 127-137.

\section{SAMMANFATTNING}

Mykotoxiners interferens på den prenatala utvecklingen hos mus.

II. Ochratoxin A inducerade teratogena effekter $i$ relation till dos och dräktighetstid.

Ochratoxin A löst i majsolja gavs via magsond i tre olika doser, 1, 2 och $4 \mathrm{mg} / \mathrm{kg}$ kroppsvikt, till CBA möss på 8:e eller 9:e dräktighetsdygnet. Den högsta dosen gavs dessutom till grupper av möss 2 dygn före eller 2, 4, 6-7, 10-14 och 16 dygn efter konception.

Exponering för högsta dosen under dräktighetsdygn 7, 8 eller 9 orsakade en minskad prenatal överlevnad och vid 9:e dygnet dessutom en reducerad fostertillväxt. En tydligt hämmande effekt på fostertillväxten förelåg även vid behandling före konception. Uppenbara kraniofaciella missbildningar uppkom endast vid exponering dygn 8 eller 9. Missbildningarnas frekvens, multiplicitet och svårighetsgrad var tydligt dosrelaterade. Högsta frekvensen missbildningar uppstod vid behandling dag 9.

Anatomiskt förelåg underutveckling och utebliven slutning av neurokraniet samt onormal konfiguration, position och storlek av benen i skallens basala och laterala väggar.

(Received October 15, 1981).

Reprints may be requested from: R. G. Arora, the Department of Pathology, Faculty of Veterinary Medicine, Swedish University of Agricultural Sciences, S-750 07 Uppsala, Sweden.

\section{APPENDIX \\ Ochratoxin A (4 mg/ $\mathrm{kg}$ ) caused foetal deaths and malformations: Statistical analysis.}

In the experiments a number of females are randomly selected and treated with the toxin during one of the gestation days or two days before mating. The number of pregnant females are denoted $\mathrm{N}$ and varies between 4 (day -2) and 26 (day 10) (Table 1). The total numbers of foetuses $n_{1}, n_{2}, \ldots n_{k} \ldots n_{N}$, are observed for the $N$ females, and also the numbers $r_{k}$ of responding foetuses.

In Table A, $r_{k}$ denotes the numbers of dead foetuses, and in Table $B$ (the upper part) the numbers of survivors malformed and (in the lower part) dead + survivors malformed. 


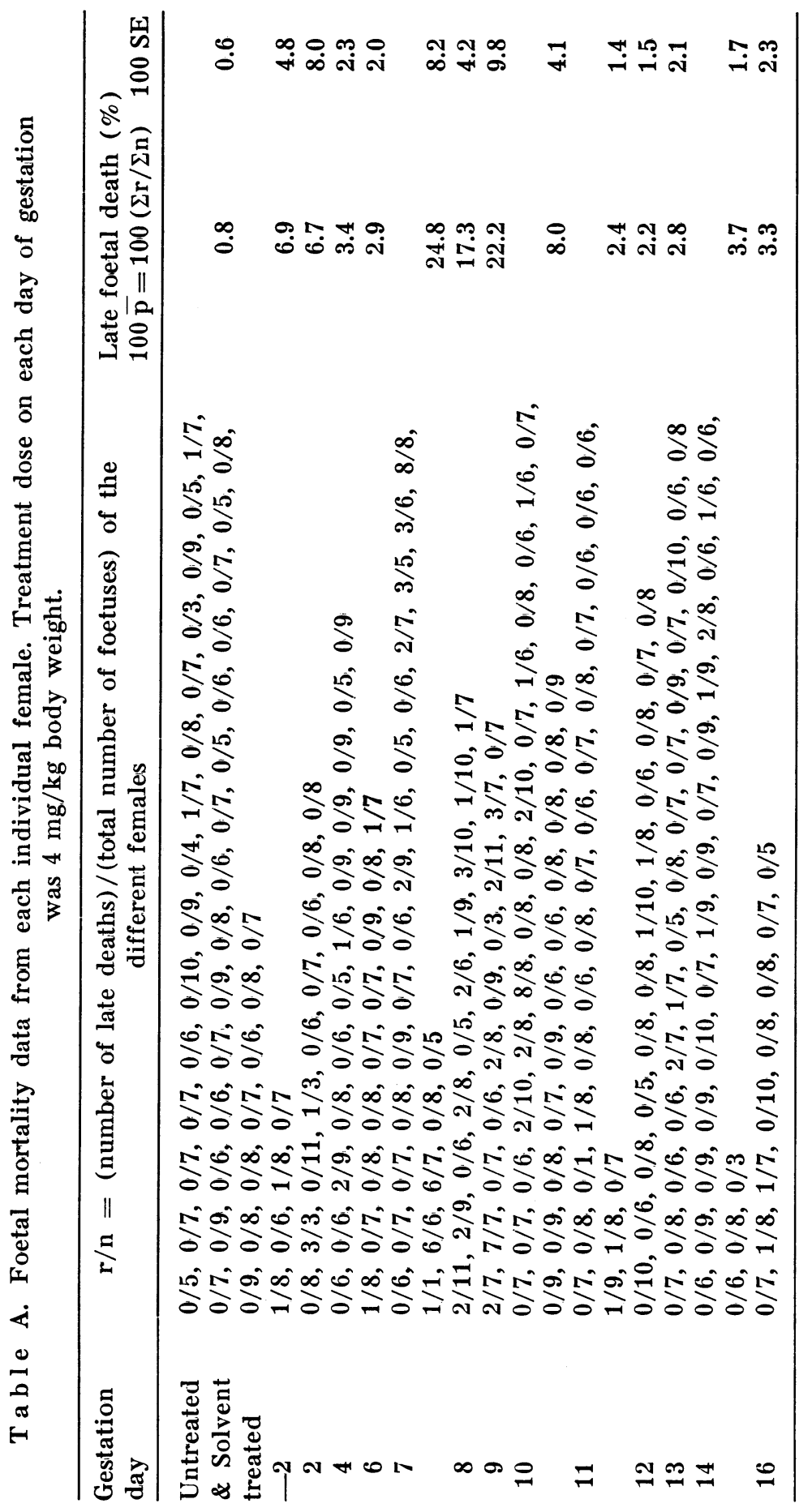


T a b l e B. Malformed foetuses from each individual female. The dose given was $4 \mathrm{mg} / \mathrm{kg}$ body weight.

\begin{tabular}{lccc}
\hline $\begin{array}{l}\text { Gesta- } \\
\text { tion } \\
\text { day }\end{array}$ & $\mathrm{r} / \mathrm{n}$ of the different females & $\begin{array}{c}\text { Foetal response }(\%) \\
100 \overline{\mathrm{p}}=100(\Sigma \mathrm{r} / \Sigma \mathrm{n})\end{array}$ & $100 \mathrm{SE}(\overline{\mathrm{p}})$ \\
\hline 8 & $1 / 11,0 / 9,5 / 6,3 / 8,0 / 5,0 / 6,0 / 9,1 / 10,0 / 10,1 / 7$ & $13.6^{\mathrm{a}}$ & 7.5 \\
9 & $5 / 7,0 / 7,7 / 7,5 / 6,6 / 8,9 / 9,3 / 3,8 / 11,3 / 7,5 / 7$ & $70.8^{\mathrm{a}}$ & 9.4 \\
\hline 8 & $3 / 11,2 / 9,5 / 6,5 / 8,0 / 5,2 / 6,1 / 9,4 / 10,1 / 10,2 / 7$ & 30.9 & 7.3 \\
9 & $7 / 7,7 / 7,7 / 7,5 / 6,8 / 8,9 / 9,3 / 3,10 / 11,6 / 7,5 / 7$ & 93.1 & 3.1 \\
\hline
\end{tabular}

r: number of foetuses, malformed (upper part) or dead or malformed (lower part).

$\mathrm{n}$ : total number of foetuses, both viable and nonviable foetuses included.

a: The corresponding percentage of malformed foetuses among the total survivors of a given treatment is given in text Table 2.

As a measure of the effect of the toxin, the pooled relative frequency

$$
\overline{\mathbf{p}}=\underset{1}{\Sigma \mathbf{r}_{\mathbf{k}}} \underset{1}{\mathbf{N} \mathbf{n}_{\mathbf{k}}}
$$

is calculated for each treatment day. These ratios are reported as percentages, i.e. $100 \bar{p}$ in the Tables $2,4, A$ and $B$.

The often used simple expressions of the variance and SE of $\bar{p}$

$$
\begin{array}{r}
\operatorname{var}(\overline{\mathrm{p}})=\overline{\mathrm{p}}(1-\mathrm{p}) /\left[\Sigma\left(\mathrm{n}_{\mathrm{k}}\right)-1\right] \\
\operatorname{SE}(\overline{\mathrm{p}})=\sqrt{\operatorname{var}(\overline{\mathrm{p}})}
\end{array}
$$

are correct only if $\bar{p}$ is a binomially distributed variable which is true if all the $\Sigma n_{k}$ foetuses may be regarded as independent experimental units with the same probability $p$ to respond. This implies that the response probability of a foetus is independent of its mother.

It will be shown, however, in the following that there are variations in $p$ on some gestation days, i.e. there are differences in the dispositions of the females to carry responding foetuses, and in such cases Eqn. (2) underestimates the variance and an alternative estimation process must be used.

According to this method an approximation of the variance of $\bar{p}$ is obtained by the formula

and

$$
\operatorname{var}(\bar{p})=\frac{\Sigma n_{k}\left(p_{k}-\bar{p}\right)^{2}}{(N-1) \Sigma n_{k}}
$$

$$
\operatorname{SE}(\overline{\mathrm{p}})=\sqrt{\operatorname{var}(\overline{\mathrm{p}})}
$$

where $p_{k}=r_{k} / n_{k}$ is the proportion of responding foetuses of $k$ :th female. 
The decision of estimation process has been founded on the so called Binomial Index of Dispersion.

$$
\mathrm{BID}=\sum_{1}^{\mathrm{N}} \mathrm{n}_{\mathrm{k}}\left(\mathrm{p}_{\mathrm{k}}-\overline{\mathrm{p}}\right)^{2} /[\overline{\mathrm{p}}(1-\overline{\mathrm{p}})]
$$

If the parameter $\mathrm{p}$ is the same for the $\mathrm{N}$ females given the same treatment, then BID is approximately distributed as $\chi^{2}$ with $\mathrm{N}-1$ degrees of freedom.

Thus, for each gestation day we test the hypothesis that the p-values are constant. A sufficient high value of BID rejects the hypothesis and makes it reasonably to assume that there are differences between the females.

When analysing the mortality data we got a significant $\chi^{2}$ for the gestation days, 2, 7, 9, 10 and 13. The same analyses are also performed on dead + survivors malformed day 8 and 9 , which are the days malformed foetuses occur. For these data, a significant $\chi^{2}$ is obtained for gestation day 8 .

These tests indicate that a "heterogenicity" between the females exists at least for some gestation days. In the Tables $A$ and $B$ the $\mathrm{SE}(\overline{\mathrm{p}})$ is calculated according to Eqn. (2) when BID $<\mathrm{N}-1$ which is the expected value when no heterogenity exists. In other cases Eqn. (3) is used. 